\title{
CSIKY-MÉSZÁROS ÁKOS
}

\section{A titkos információgyüjtés és titkos adatszerzés alapjogi problémái}

Az eredményes és törvényes bünüldözés érdekében szükségesnek bizonyult olyan vezérelvek rögzítése, amelyek a demokratikus államok konszenzusán alapulnak.

A hazai szabályozást figyelembe véve, az ágazati jogszabályok mellett az alaptörvényből és az Alkotmánybíróság munkájából kell kiindulnunk, amelyek jogrendszerünk legfontosabb építőkövei.

Az alaptörvény B) cikk (1) bekezdése szerint „Magyarország független, demokratikus jogállam”, ami annyit tesz, hogy a jog uralma érvényesül, amelynek legitimációja a (3)-(4) bekezdésben megfogalmazott népszuverenitásból ered. Az I. cikk (1) bekezdése értelmében ,, $A Z$ EMBER sérthetetlen és elidegenithetetlen alapvetö jogait tiszteletben kell tartani. Védelmük az állam elsörendü kötelezettsége”. A (3) bekezdés oly módon rögzíti a védelem eszközét, hogy ,,az alapvetö jogokra és kötelezettségekre vonatkozó szabályokat törvény állapitja meg. Alapvetö jog más alapvetö jog érvényesülése vagy valamely alkotmányos érték védelme érdekében, a feltétlenül szükséges mértékben, az elérni kivánt céllal arányosan, az alapvetö jog lényeges tartalmának tiszteletben tartásával korlátozható." Ez megfeleltethető az Alkotmánybíróság 30/1992. (V. 26.) AB határozatában foglalt szükségesség és arányosság követelményének, ami jogrendszerünkben elsődleges alapjogi tesztként müködik.

\section{Szükségesség és arányosság}

Alkalmazása során vizsgálni kell, hogy van-e olyan legitim cél, amelynek érdekében a jogkorlátozás elengedhetetlen (szükségesség), így az alaptörvény megfogalmazása szerint, egy másik személy alapjoga, vagy éppen egy alkotmányos érték. Második lépésként a jogkorlátozás mibenlétét, mértékét kell szem elött tartanunk (arányosság). Ennek egyik eleme az alkalmasság, vagyis annak a logikai összefüggésnek a vizsgálata, hogy az eszköz képes-e beteljesíteni az elérni kívánt célt. Ezen felül analizálni kell a tágabb értelemben vett 
szükségességet, a szabályozás elkerülhetetlenségét, tehát azokat az esetleges lehetőségeket, amelyek szintén megoldást kínálhatnak a problémára. Végül pedig meg kell nézni, hogy szük értelemben is érvényesül-e az arányosság követelménye, hogy a cél és az okozott jogsérelem arányban áll-e egymással.

Ebből kiindulva a szükségesség oldalán felvetődnek olyan jogok, amelyeket a fedett nyomozás során végzett intézkedések érintenek, így az alaptörvény II. cikke kimondja, hogy ,, az emberi méltóság sérthetetlen” és azt, hogy minden embernek joga van a méltósághoz. Az Alkotmánybíróság a 23/1990. (X. 31.) AB határozatában szubszidiárius alapjogként kezeli az emberi méltósághoz való jogot, így az felhívható minden olyan esetben, amikor más nevesített alapjog nem áll rendelkezésre, aminek következtében általános személyiségi jogi jelleget ölt. Jelentősége abban áll, hogy abszolút jelleggel érvényesül, és az élethez való joggal együtt alkalmazva már korlátozhatatlanná válik. Emellett anyajogként funkcionál, vagyis más jogok forrásaként jelenik meg, ezáltal levezethető belőle a VI. cikkben foglalt magán- és családi élethez való jog, az otthon, a kapcsolattartás, a jó hírnév tiszteletben tartásához füződő jog. Szintén ehhez tartozik, hogy a (2) bekezdés alapján ,, mindenkinek joga van személyes adatai védelméhez, valamint a közérdekü adatok megismeréséhez és terjesztéséhez", amelynek biztosítását egy sarkalatos törvényben felállított szerv, a Nemzeti Adatvédelmi és Információszabadság Hatóság végzi. A 2/2007. (I. 24.) AB határozat kiemeli még ezzel kapcsolatban a magántitokhoz, a magánlakás sérthetetlenségéhez való jogot, ugyanis egy lehallgatás vagy a postai küldemény átvizsgálása során ezek a jogok könynyen sérelmet szenvedhetnek. Ezek a módszerek az életünk olyan intim területeibe engednek betekintést, amelyeket a hozzánk közel álló személyekkel sem mindig osztunk meg, tehát egy közhatalmat gyakorló állami szerv különösen nagy veszélyt jelent az „én” integritására nézve.

$\mathrm{Az}$ arányosság kapcsán ugyancsak a 2/2007. (I. 24.) AB határozat adhat támpontot. Ebben az Alkotmánybíróság megállapította azokat a minimumfeltételeket, amelyek esetén elrendelhető a titkos információgyüjtés és a titkos adatszerzés. Ennek eredményeképpen a büntetőeljárásról szóló 1998. évi XIX. törvény (a továbbiakban: Be.) 201. § (1) bekezdésének szövegét nagyrészt hatályon kívül helyezte, mert az nem felelt meg a normavilágosság követelményének. A határozat az indokolásában külföldi példákból merítkezik, amelynek során számba veszi a lehetséges megoldásokat a szabályozás kérdésében. Így láthatjuk, hogy a német rendszer az általános feltételek mellett taxatíve felsorolja azokat a büncselekményeket, amelyek gyanúja esetén az egyes eszközök és módszerek alkalmazhatók. Hollandiában a tettenérésnek, az őrizetbe 
vétel megengedhetőségének és a büntetési tételeknek van súlyuk, míg Ausztriában a kiszabható szabadságvesztés mértéke a meghatározó a döntésben. Ezzel szemben az Egyesült Királyságban az úgynevezett vegyes megoldás az irányadó, amelyben az egységesen meghatározott általános feltételek mellett részben a szabadságvesztés mértéke van befolyással az alkalmazhatóságra, másrészt pedig vannak törvény által felsorolt büncselekmények is, amelyek olyan súlyúak, hogy azok már eleve igazolják az igénybevételt. Mindezeket egybevéve is érvényesül, hogy ezekben az államokban is csak ultima ratio jellege van a nyomozás e módjának annak érdekében, hogy az alapvetően titkos és sajátos eszközöket használó tevékenységek ,,semmilyen körülmények között ne jelenthessenek veszélyt a demokratikus jogrendre" [16/2001. (V. 25.) $\mathrm{AB}$ határozat].

Az Alkotmánybíróság döntése és a jelenleg hatályban lévő Be. szövege szerint kimondhatjuk, hogy a magyar modell is a vegyes rendszer elemeit hordozza magában a titkos adatszerzés viszonylatában, mivel megtalálhatók benne az általános feltételek, a szabadságvesztés mértékének jelentősége, amelyet legalább ötévi szabadságvesztésben állapítottak meg, valamint azok a büncselekmények, amelyek automatikusan maguk után vonhatják a titkos adatszerzés használatát. Ebben a tekintetben érvényesül a legalitás elve azáltal, hogy a jogalkotó külön megnevezi a Be. 201. § (1) bekezdésében azokat a büncselekményeket, amelyek körében nincs lehetőség az engedélyező hatóság mérlegelésére. Hasonló megoldás jelentkezik a rendőrségről szóló 1994. évi XXXIV. törvényben (a továbbiakban: Rtv.) is, amelynek 69. § (3) bekezdése felsorolja, hogy milyen esetekben jogosult a rendőrség büncselekmény gyanúja miatt felderítést végezni a titkos információgyüjtés elrendelésekor.

\section{A különleges eszközök szabályozása}

A titkos adatszerzésre vonatkozó alapvető szabályokat a Be. tartalmazza, ugyanis ez csak a nyomozati szakaszban értelmezhető, ami az eljárásjog hatálya alatt áll, emiatt az elhelyezése az alaki jogforrásban indokolt. Megfogalmazását illetően a 200. § (1) bekezdés kimondja, hogy ,, az ügyész és a nyomozó hatóság bírói engedély alapján az elkövető kilétének, tartózkodási helyének megállapitása, elfogása, valamint bizonyitási eszköz felderitése érdekében a nyomozás elrendelésétöl a nyomozás iratainak ismertetéséig az érintett tudta nélkül" rögzítheti és használhatja fel a megszerzett adatokat. A 
nyomozás mint választóvonal kap szerepet a (4) bekezdésben is, miszerint „, ha a nyomozás elrendelését megelözően külön törvény alapján a bíró, illetöleg az igazságügyért felelös miniszter által engedélyezett titkos információgyüjtés végrehajtása során az ügyben a nyomozást elrendelik, a titkos információgyüjtést a továbbiakban csak e törvény szerint mint titkos adatszerzést lehet folytatni".

Ezzel szemben a titkos információgyüjtés mint jogintézmény részletesebben az Rtv.-ben van szabályozva, annak ellenére, hogy az eredményének elbírálása a büntetőeljáráshoz kapcsolódik, amelynek során a tárgyaláson bizonyítékként szolgál. Az Rtv. 63. § (1) bekezdése szerint ,, a rendörség büncselekmény elkövetésének megelözése, megakadályozása, felderitése, megszakitása, az elkövetö kilétének megállapitása, elfogása, körözött személy felkutatása, tartózkodási helyének megállapitása, bizonyitékok megszerzése, a büncselekményböl származó vagyon visszaszerzése, valamint a büntetöeljárásban részt vevők és az eljárást folytató hatóság tagjainak, az igazságszolgáltatással együttmüködö személyek védelme, valamint az e törvényben meghatározott költségvetési szervek bünmegelözési, bünfelderitési célú ellenörzése érdekében - törvény keretei között - titokban információt gyüjthet". A végrehajtáshoz füződően a nemzetbiztonsági szolgálatokról szóló 1995. évi CXXV. törvény (a továbbiakban: Nbtv.) is iránymutatást ad, amely a szervezet hatáskörébe delegálja a különleges eszközök alkalmazását, az információszerzés megvalósítását. Megállapíthatjuk tehát, hogy a titkos információgyüjtés a nyomozás előtti szakaszhoz kapcsolódó tevékenység, így dogmatikailag jobban kötődik ahhoz a hatósághoz, amely ezt a tevékenységet folytatja, mintsem ahhoz, amelyik majd a későbbiekben dönt a létrejött információk felhasználhatósága felől; ebből a szempontból indokolt a kérdést az anyagi jogszabályok között tisztázni. Az eljárási szabályok a törvényben az engedélyeztetésre szükülnek, vagyis arra, hogy mely úton lehet megszerezni a végrehajtás legalizálásához szükséges bírói határozatot.

A megszerzett információk érvényesíthetőségét tekintve azonban bizonyos rendelkezéseket a Be.-nek is tartalmaznia kell, ahogy azt az Alkotmánybíróság is megállapította a már hivatkozott 2/2007. (I. 24.) AB határozatban. A 2006. június 30-án hatályban volt Be. 206. § (3) bekezdése alkotmányellenesnek bizonyult, amiért nem rendezte a titkos információgyüjtés eredményének felhasználását, csupán a titkos adatszerzésre vonatkozó paragrafusok analógiájára lehetett támaszkodni annak ellenére, hogy a két jogintézmény nem egészen feleltethető meg egymásnak. Ez a szabályozatlanság öncélú jogalkalmazáshoz vezethetett, abból a joghézagból eredően, hogy nem voltak 
meg az erre a tárgykörre irányuló eljárási szabályok. A büntetőjog alapelvei között szerepel a normavilágosság követelménye, vagyis hogy az adott jogszabály mindenki számára érthető legyen és mindenkinek ugyanazt a jelentést hordozza, továbbá az analógia tilalma, ami azt hivatott megakadályozni, hogy a jogalkalmazók túl nagy teret kapjanak a jogértelmezés során, amely esetleg az önkény eszköze lehet. A különleges eszközökkel szerzett információk nagyban befolyásolhatják a tárgyalást lezáró határozat tartalmát, ezért fontos, hogy a szabályok teljes körüek legyenek, zárt egységet alkossanak, és ne tegyék lehetővé a jogszabályok egyedi értelmezését.

\section{A jogforrási hierarchián kívülről érkező hatás}

A törvényeken kívül viszont számos más forrás képes befolyásolni a bíróságok müködését, amelyek nem jogforrások ugyan, ám mégis kötelezők vagy éppen követendök az egyes ügyek eldöntése kapcsán. Ilyen módon érvényesül az Alkotmánybíróság határozata, mind az utólagos konkrét normakontroll, mind pedig az alkotmányjogi panasz tekintetében, a Kúria Büntető Kollégiumának véleménye, valamint az ítélkezési gyakorlat. Utóbbi hazánkban nem bír akkora jelentőséggel, mint például az angolszász jogrendszerekben, de van precedens jelentősége, és az egyes indokolások más határozatokban is hivatkozási alapul szolgálhatnak, hiszen így szavatolható a következetesség, a kiszámíthatóság és a jogfolytonosság annak ellenére is, hogy minden ügyet egyedileg, az adott tényállásra vonatkozóan kell elbírálni.

\section{Haladéktalanság}

Az egyik legnagyobb elvi jelentőségü forrás ezen a területen a 74/2009 BK vélemény, amely iránymutatást ad a titkos információgyüjtés és a titkos adatszerzés felhasználásának eljárási szabályai kapcsán. Ennek egyik lényeges eleme rendezi a Be. akkor hatályos 206/A § (1) bekezdésének azon fordulatát, miszerint a titkos információgyüjtés eredménye, a 201. §-ban meghatározott feltételek mellett, akkor használható fel, ha „, az engedélyezést kérő szerv a feljelentési kötelezettségének haladéktalanul eleget tett". Ez mára annyiban módosult, hogy a hatóságnak a nyomozást „nyomban el kell rendelnie”, vagy a feljelentési kötelezettségének ,nyomban eleget kell tennie”, azonban a jelentése és a terminológiai értelme nem sokat változott, a fogalom ugyan- 
annyira megfoghatatlan és relatív maradt. A „haladéktalanság” követelményére az Alkotmánybíróság korábban sem tudott kielégítő megoldást nyújtani, ugyanis szerinte ez mindig az adott körülmények függvényében változik, így nem lehet meghatározni olyan időintervallumot, amely minden esetben általánosan elfogadott mértékül szolgálhatna. A véleményben a kollégium kitér arra, hogy az ügyek eltérő jellege, bonyolultsága és az adatmennyiség változó terjedelme az, ami befolyással van a kérdéskör összetettségére. Kifejti, hogy a Nemzetbiztonsági Szakszolgálat az Nbtv. 8. § (1) bekezdésében foglalt jogkörének gyakorlása során nagy mennyiségü információt tartalmazó anyagot ad át a titkos információgyüjtést végző hatóságnak. Ebben relevánsnak számítanak azok az adatok, amelyek alkalmasak a Be. 201. § szerinti feltételek alátámasztására és ezáltal a gyanú megállapítására, továbbá azok, amelyek arra engednek következtetni, hogy a büncselekmény elkövetésére utaló adatok azzal a személlyel hozhatók kapcsolatba, akivel szemben a titkos információgyüjtést elrendelték, valamint amelyek az engedélyben nem szereplö más személyek által elkövetett büncselekmények bizonyítására is sikeresek lehetnek. Ezzel szemben ki kell szürni és meg kell semmisíteni azokat a megszerzett ismereteket, amelyek az ügy kimenetele szempontjából érdektelenek, vagy olyan személyekre irányulnak, akik nem érintettek sem az eredeti, sem egy másik eljárásban. Az ágazati törvények, így az Rtv., vagy az Nbtv. nem szabnak határidőt a jelentőséggel bíró információk kiszürésére, ezért a vélemény szerint célszerủ a Be. azon rendelkezéséből kiindulni, hogy a titkos adatszerzés körében a 204. § (4) bekezdése a felesleges adatok kiszürésére és megsemmisítésére nyolc napot enged. Ebből kifolyólag a nyomban történő intézkedés követelménye még nem sérül akkor, ha a titkos információgyüjtést végző szerv nyolc napon belül nem indítja meg a nyomozást, vagy nem tesz feljelentést, mivel az akkor összegyüjtött adathalmaz még erre nem áll készen. A titkos adatszerzés a nyomozás alatt célzottabban folyik, mint a titkos információgyüjtés abból adódóan, hogy ez az eljárás már nem bünmegelőzési vagy bünfelderítési célból történik, hanem egy konkrét büncselekmény kapcsán, tehát vélhetően az adatmennyiség is kevesebb, ugyanis jobban behatárolható az a személy, csoport, akivel/amellyel szemben ezeket az eszközöket alkalmazzák.

Ezt az álláspontot fogadta el a Debreceni Ítélőtábla is a DIT-H-BJ-2012125. bírósági határozatában, amely szerint a vádlott védője arra alapozta a fellebbezését, hogy a titkos információgyüjtés eredménye nem lett volna felhasználható a bizonyítékok között. Az ügyvéd azt kifogásolta, hogy a 2010. március 31-én elkövetett büncselekmény és a 2010. május 4-én tett feljelen- 
tés között olyan hosszú idő telt el, ami nem feleltethető meg a haladéktalanság követelményének. Az ítélötábla a fellebbezési kérelem e pontjának a Kúria véleményét követve nem adott helyt azzal érvelve, hogy a vélemény, a Be.-hez hasonlóan, ,nem állapitott meg sem relativ, és különösen nem abszolút határidöt a haladéktalan feljelentés fogalmának értelmezésére”. Ennek jelentősége elsősorban akkor áll fenn, amikor , a más ügyben elkövetett büncselekmény gyanúja miatt elrendelt titkos információgyüjtés bíróság által engedélyezett határidejének lejárta elötti esetleges feljelentés a titkosszolgálati eszközök alkalmazásának idö elötti felfedését, és ez által a bünüldözési célok ellehetetlenülését eredményezhetné”. Különösen érvényes ez abban az esetben, amikor ezeknek a módszereknek az alkalmazása során egy másik büncselekményre is fény derül, ugyanis a Be. 171. § (2) bekezdése szerint a hatóság köteles feljelentést tenni az olyan büncselekmény kapcsán, amelyről hatáskörének gyakorlása során szerzett tudomást. Mivel ez veszélyeztetné az eredeti célponttal szemben való sikerességet, ezért a hatóságnak jogában áll azután eleget tenni a kötelezettségének, miután a különleges eszközök alkalmazásának határideje már lejárt.

A kérdéshez kapcsolódóan nem tisztázott, hogy a feljelentési kötelezettségnek a tudomásszerzéshez, a bizonyíték beszerzéséhez, vagy a büncselekmény befejezettségéhez kell-e igazodnia. Ennek a dilemmának a jelentősége egy folyamatban lévő büncselekmény esetén élesedhet ki, amikor is a nyomozó hatóság még az előtt megismeri az erre utaló információkat, mint ahogy az ténylegesen befejezetté válna. Ilyen eset vetödhet fel például egy vesztegetés során akkor, ha az eljáró szervek tudomást szereznek az ajánlat megtételéről és az ajánlat elfogadásáról, a pénz átadására viszont csak később kerül sor. Ekkor a bizonyítás szempontjából a hatóságoknak az átadáson történő jelenlétnek lenne a legnagyobb haszna, ellenben a büncselekményről való tudomásszerzés ekkor már végbe ment, de a lényeges kivetülés csak a jövőbeli teljesítéssel áll be.

A társadalmi érdekkel összeegyeztethető az az álláspont, hogy az elkövetők minél nagyobb száma ellen induljon meg az eljárás, és hogy azok az igazságszolgáltatás sikerével záruljanak, mert így gazdaságosabb és eredményesebb lehet a müködés. Ennek kínál lehetőséget a Be. 171. § (2) bekezdésének második fordulata, amely szerint a feljelentéshez csatolni kell a bizonyítási eszközöket, de ha erre nincs mód, akkor a megörzésükről kell gondoskodni, mert így biztosítható, hogy a megalapozott gyanú közlése során a titkos adatszerzés tényéről a terhelt ne szerezzen tudomást és erről mást se tudjon értesíteni. Ebből eredően alkalom nyílik arra is, hogy ne a büncselekmény tudo- 
másra jutása legyen a kiindulópont, hanem az ennek alátámasztásául szolgáló bizonyítékok beszerzése, vagyis jelen esetben az átadás leleplezéséről készült jegyzőkönyv.

Sem a törvény, sem a Kúria véleménye nem ad kielégítő választ a probléma rendezésére, ám véleményem szerint ebben az esetben a feljelentési kötelezettségnek a bizonyítékok begyüjtéséhez kellene igazodnia, nem pedig a tudomásszerzéshez. Az ártatlanság vélelméhez füződően indokoltabb lehet egy olyan szabályozás, ami garantálni tudja az eljárás biztosabb alapokra történő helyezését. Ennek következtében csak akkor indulna meg a nyomozás, ha már a hatóságok tényleges bizonyítékok birtokában vannak, és nem csak elméletekre alapozva tennék ki a feltételezett elkövetőket a büntetőeljárásnak. Ha a terhelt egy telefonbeszélgetés során egy barátjának azt állítja, hogy megvesztegetett valakit, az még nem jelenti azt, hogy a büncselekmény valóban megtörtént; erre utaló bizonyítékok hiányában a büntetőeljárás megindítása értelmetlen lenne egy folyamatban lévő büncselekmény esetén, amelynek a tárgyi súlya kisebb, mint például egy emberölésnek, amikor is a társadalmi érdek a büncselekmény megakadályozása mellett szól. Ebben az esetben nyilvánvalóan nem engedhető meg, hogy a hatóságok várjanak a gyilkosság elkövetéséig.

Ha a feljelentési kötelezettséget a bizonyítékok megszerzésének időpontjához kötjük, akkor azzal a nyolcnapos határidő is könnyebben értelmezhetővé válik, és egységesebbé tehető az eljárás megítélése.

\section{Az engedélyhez szükséges indokolás tartalma}

A 74/2009. BK vélemény másik fontos kérdésköre az engedélyezéssel kapcsolatos szabályok, amelyek keretet adnak a hatóságoknak a különleges eszközök alkalmazása során, mind időben, mind a felhasználható módszerek terén. A jogszabályi hátteret figyelembe véve megállapítható, hogy az Rtv. 70. § (2) bekezdés a kérelem tartalmi követelményének a ,különleges eszköz alkalmazásának helyét, az alkalmazással érintett nevét, illetöleg az azonositásra alkalmas - rendelkezésre álló - adatot”, a felhasználni kívánt eszköz megnevezését és annak tervezett kezdetét és végét, napban és órában meghatározva, valamint a törvényi feltételek meglétére vonatkozó indokolást tekinti, ennél viszont az Nbtv. sem igazán kíván meg többet. Különbségek az eltérő hatáskörből eredően észlelhetők ugyan, ám az időre vonatkozó szabályok megegyeznek (bár a csak napokban történő behatárolás valamivel tágabb le- 
hetőséget kínál, mint a „napokban és órákban” kikötés). Ezekből kiindulva a vélemény leszögezi, hogy a szigorú jogszabályi korlátok nem engednek eltérést az engedélyben megjelölt időtartamhoz képest, azt nem lehet kibővíteni, attól nem lehet eltérni. A Be. annyiban követel meg többet, hogy a nyomozást végző hatóságnak a titkos adatszerzésre vonatkozó kérelemben a 203. § (1) bekezdés e) pontja szerint részletes leírást kell adnia a 201. és 202. §-ban foglalt kritériumok fennállásról. Erre azért van lehetőség, mert az említettek szerint ez a tevékenység már a nyomozati szakaszban történik, tehát a nyomozó hatóság rendelkezésére áll egy gyanúsított és egy büntetendő cselekmény, ezek a titkos információgyüjtés idején még nem feltétlenül vannak jelen, ezáltal a kérelem indoklása is könnyebben árnyalható, alátámasztható. Ennek következtében itt már elvárható a büncselekmény vagy éppen a gyanúsított megnevezése is.

Ebből a különbözőségből fakadó probléma jelentkezik a DIT-H-BJ-2007-41. bírósági határozatban is, amelyben a Szabolcs-Szatmár-Bereg Megyei Bíróság 2006-os ítéletével kapcsolatos fellebbezési kérelmet vizsgált meg a bíróság, amiben a vádlott védője szerint a titkos információgyüjtést végző szerv nem tett eleget az indokolási kötelezettségének. Az ítélőtábla nem adott helyt ennek az álláspontnak, ugyanis az erre vonatkozó törvényi szabályozásban „, sem az eljárás alá vont gyanúsitott (terhelt), sem az információgyüjtés alapjául szolgáló büncselekmény megjelölése nem szerepel" mint követelmény. Az Rtv. és az Nbtv. egyaránt ,alkalmazással érintett személyröl” szól, ami annak tulajdonítható, hogy ennek az eszköznek a végrehajtása a ",felderitési szakaszban zajlik, melyben a büncselekmény tényállása, ennek megfelelöen az eljárás tárgyát képező cselekmény(ek) jogi minösitése, a terheltként később felelösségre vonható elkövetők köre pontosan nem ismert”. Ezen oknál fogva nincsenek olyan ,,személyi vagy tárgyi korlátozások, amelyek kizárólag a birói engedélyben megjelölt személyre szükitenék az információk bizonyitékként történö alkalmazását". Ha a hatóságok ezeket jogszerüen szerezték be, abban az esetben a büntetőeljárás során felhasználhatók, és a Be. 78. § (4) bekezdésének alkalmazására nincs mód, nem zárhatók ki a bizonyítékok közül.

Ennek kapcsán viszont felvetődik a kérdés: meddig is terjeszkedhet ezeknek a különleges eszközöknek a végrehajtása? Mivel elöre nem tudjuk felmérni azt, hogy a megfigyelés alatt álló személy kikkel érintkezik a jövőben, kikkel lép kapcsolatba, ezért akarva, és jobb esetben akaratlanul, olyan személyek válhatnak a felderítés vagy a nyomozás alanyává, akiknek az adott ügyhöz nincs közük. Az ártatlanság vélelme, vagyis a büntetőeljárás-jog egyik 
legfontosabb alapelve szerint, senkit sem lehet bünösnek tekinteni jogerős bírósági ítélet nélkül. Ehhez mérten alkotmányossági aggályokat vet fel, ha az alapjogok korlátozása túlnyúlik a jogállamiság követelményén és legitim ok nélkül csorbítja harmadik személyek jogait. A Be. 202. § (2) bekezdése értelmében akkor is lehetőség nyílik az ügyben nem érintett személlyel szemben titkos adatszerzésre, ha a gyanúsítottal, vagy azzal a személlyel, aki „, a büncselekmény elkövetésével a nyomozás addigi adatai alapján gyanúsitható”, bünös kapcsolattartásra adat merül fel, vagy ilyen kapcsolat megalapozottan feltehetö.

Az Alkotmánybíróság a már korábban említett 2/2007. (I. 24.) AB határozatában foglalkozott ezzel a problémával, és megállapította, hogy ezáltal az alanyi kör kiterjesztésének nem akadálya az sem, ha az a további, ,, a feltételezett bünös kapcsolatokon kívülálló, ám velük kapcsolatba lépö, vagy kapcsolatba lépö harmadik személyeket is érint”. Leszögezik, a bünös kapcsolattartás nem büntetőjogi kategória, ennél pedig még absztraktabb az a kifejezés, hogy a „kapcsolat megalapozottan feltehetö”, ami valószínüleg nem állja meg a helyét a szükségesség és arányosság tesztjével szemben, ugyanis egy vélelmezett érintkezés nem támasztja alá kellőképpen azt a legitim célt, ami elfogadhatóvá tenné az alapjog korlátozását. A határozat szerint a titkos információgyüjtés esetén a bünüldözési, valamint a nemzetbiztonsági érdek ütközik meg a magántitokhoz való joggal, amely „önmagában véve is olyan erös alapjog, mely elválaszthatatlan kapcsolatban áll más alapjogokkal: az emberi méltóságból következö általános cselekvési szabadsággal, a személyiség szabad kibontakoztatásával, a kommunikációs alapjog önrendelkezésre vonatkozó aspektusával”. A korlátok nélküli alkalmazhatóság így könnyedén válhat szinte bárki megfigyelésének eszközévé, és az alapjogok kiüresedése következhet be már a közérdekre, közbiztonságra való puszta hivatkozással is.

Továbbá a megfigyelés tárgyi alapjára irányulóan aggályként vetődhet fel az, ha a megadott engedélyben szereplö büncselekményre vonatkozó adatra nem derül fény a különleges eszközök alkalmazása közben, azonban egy másik büncselekményre igen, aminek kapcsán lehet, hogy nem is álltak volna fenn az engedélyezéshez szükséges feltételek. A hatóságokat ekkor is terheli a feljelentési kötelezettség, aminek a törvényből fakadóan eleget kell tenniük, ellenben álláspontom szerint a titkos adatszerzést erre vonatkozóan haladéktalanul be kell fejezni, és az ily módon megszerzett bizonyítékok nem használhatók fel a perszakaszban, ugyanis nem teljesülnek az engedélyezéshez füződő követelmények. Ha a bíróság figyelembe venné az így megszer- 
zett anyagot, azzal a lényegétől fosztaná meg a nyomozási bíró munkáját, vagyis pont azt a döntéshozói elemet hagynák ki az eljárás menetéből, amely képes lenne kontrollt gyakorolni rá, és amelyik a tisztességes eljárás elvét lenne hivatott biztosítani az alapjogok védelme érdekében. Erre irányuló szabály hiányában ez egy olyan gyakorlattá válhatna, amelynek révén bárki ellen eljárás indulhatna egy olyan büncselekmény gyanúja miatt, amelynek a valóságban nem létezik alapja, mivel az engedély elsősorban az alkalmazhatóság időbeli korlátját és eszközét szabná meg, a felderítés céljához, általános követelményeihez viszont nem illeszkedne. Ez a lehetőség olyan szabad mozgásteret adna a közhatalmi szerveknek, amelyet egy jogállam nem engedhet meg magának.

A titkos adatszerzés körében a Be. 206. § (3) bekezdése leszükíti a bizonyítékként történő felhasználtságot az engedélyben szereplő büncselekményre és az abban megnevezett személyre, a (4) bekezdés pedig kimondja, hogy a különleges eszközök alkalmazásához szükséges feltételeknek is fenn kell állniuk akkor, ha az eljárás nem az engedélyben megjelölt büncselekmény kapcsán indul. Ettől függetlenül az eljárás a feljelentési kötelezettség miatt az enyhébb súlyú büncselekmény kapcsán megindul, amelynek bizonyítása vélhetően a már rendelkezésre álló adatok alapján könnyebb lesz annak ellenére is, ha a titkos adatszerzés eredménye nem is lesz felhasználható a tárgyaláson. A hatóságok immáron tudják, hogy a szükséges bizonyítékok milyen módon lesznek beszerezhetők, vagy hogy a feltételezett elkövetőt mikor lehet tetten érni egy büncselekmény elkövetése során.

Ezzel szemben a titkos információgyüjtés esetében csak a 206/A § (1) bekezdésében lévő feltételeknek kell teljesülniük; személyekre vonatkozó szabályozást a törvény szövege nem tartalmaz. Ez arra vezethető vissza, hogy ezeknek a módszereknek a használata során még csak a felderítés folyik, ezáltal a jogalkotó tágabb körben engedi érvényesülni a nyomozó hatóságok munkáját. Ez azonban ahhoz vezet, hogy sérül az engedélyhez és célhoz kötöttség elve, így lényegében bármilyen adat felhasználhatóvá válik függetlenül attól, hogy eredetileg kivel szemben folytatták le a végrehajtást. Kontrollként csupán az a szabály jelenik meg a (2) bekezdésben, hogy „az engedélyezést kérô szerv a nyomozás elrendelésével vagy a feljelentés megtételével egyidejüleg kezdeményezi az illetékes ügyésznél a titkos információgyüjtés eredményének a büntetöeljárásban bizonyitékként történö felhasználására való alkalmasságának megállapitását". Ebből következően az ügyész lesz az a szereplö, aki határoz arról, hogy a megszerzett adatok közül milyen 
ismeretekre alapozva nyújtja be a vádiratot, amelyre aztán megindul az elsőfokú tárgyalás.

Az eljárás tisztességének megőrzése érdekében a Be. 207. § (2) bekezdés b) pontja a felhasználhatóság kérdésének végső eldöntését a nyomozási bíró hatáskörébe utalja. Ezáltal jobban összhangba kerülnek a titkos információgyüjtés és a titkos adatszerzés eljárásjogi szabályai, aminek révén következetesebbé válik a bizonyítási eszközként való értékelésük. Emellett pedig garanciális oka van annak, hogy nem az igazságszolgáltatás azon alanya rendelkezik ezeknek a módszereknek az eredményéről, akinek éppen a vád képviselete a legföbb feladata. Ennek hiányában a terhelt olyan mértékü hátrányból indulna már az perszakasz legelejétöl kezdve, amellyel szemben a sikeres védekezésnek elenyésző esélye van, mivel ha az egyik fél kezébe adjuk a játékszabályok meghozatalának lehetőségét, vagyis annak eldöntését, hogy milyen eszközök lesznek felhasználhatók az eljárás alatt, akkor az a másik fél számára sosem lesz kedvező végkimenetelü.

Lehet érvelni amellett, hogy a társadalom érdeke és a közrend, közbiztonság védelme indokolttá teszi az eljárás megindítását és a különleges eszközök alkalmazásának engedélyezését e nélkül a szürő nélkül is, azonban szem előtt kell tartanunk azt a tényt, hogy a nyomozó hatóságok és a bíróság sosem lehet száz százalékig biztos a történeti tényállás kapcsán, ugyanis a bizonyítottság valószínüségének e foka a gyakorlatban aligha létezik. A Be. is csak a bíró belső meggyőződésétől teszi függővé a bizonyítás eredményét, amire majd a bíróság határozata épül, azonban a bizonyítékok nem mindig a valós képet mutatják be, tehát a teljes bizonyosság valójában sosem áll rendelkezésre. A nyomozás alatt elkövetett hibák, téves döntések befolyásolhatják a hatóságok megítélését a bizonyítékok kapcsán, éppen ezért szükség van egy független személy általi felülvizsgálatra, értékelésre.

\section{A nyilvánosság érvényesülése}

Végső soron eljárásjogi garanciák nélkül lehetetlen kezelni egy olyan eszközt, amelynek az elsődleges célja éppen az, hogy senki se vehessen róla tudomást. Az igazságszolgáltatásnak nem lehet az a mottója, hogy: ,,mindenki ismerheti azt a formát, amellyel győzelmet arattunk, de senki ne ismerje azt a formát, amellyel a gyözelmet megszerveztük", ám a titkos információgyüj-

\footnotetext{
1 Szun-ce: A hadviselés törvényei. Zrínyi Kiadó, Budapest, 1963.

http://mek.oszk.hu/01300/01345/01345.htm
} 
tés és titkos adatszerzés körében olykor mégis ez tünik a leginkább meghatározónak.

Az Emberi jogok európai egyezményének 6. cikk 1. pontja definiálja a „fair eljárás” elvét, e szerint: „, Mindenkinek joga van arra, hogy ügyét a törvény által létrehozott független és pártatlan biróság tisztességesen nyilvánosan és ésszerü időn belül tárgyalja, és hozzon határozatot polgári jogi jogai és kötelezettségei tárgyában, illetöleg az ellene felhozott büntetöjogi vádak megalapozottságát illetően. Az itéletet nyilvánosan kell kihirdetni." Ezzel szemben az alaptörvény a XXIV. cikk (1) bekezdésében általánosságban rögzíti a hatóságok tevékenységével kapcsolatosan a részrehajlás nélküli ügyintézés, a tisztességes eljárás, és az észszerü határidőn belül történő intézkedés követelményét, a büntetőeljárás nyilvánosságára vonatkozó részletszabályokat azonban a Be. tartalmazza. A 231. § (1) és a 239. § (2) bekezdés szerint „, a bíróság tárgyalása nyilvános”, és a tárgyaláson hozott határozat rendelkező részét teljes terjedelmében, indokolását pedig, ha az zárt tárgyalásra okot adó körülményt nem tartalmaz, akkor is nyilvánosan hirdeti ki a bíróság, ha a tárgyalásról egyébként a nyilvánosságot kizárta. Ezzel összefüggésben probléma azon az alapon vetődik fel, hogy a hatóságok a gyakorlatban majdhogynem minősített adatként kezelik a titkos információgyüjtés, valamint a titkos adatszerzés útján beszerezett adatokat, holott ezek nem teljesítik az információs önrendelkezési jogról és az információszabadságról szóló 2011. évi CXII. törvényben (a továbbiakban: Infotv.) foglalt minősítés követelményét. E törvény 3. § 4. pontja alapján ,, a büntetöeljárás során vagy azt megelözöen a büncselekménnyel vagy a büntetöeljárással összefüggésben, a büntetöeljárás lefolytatására, illetve a büncselekmények felderitésére jogosult szerveknél" keletkezett adatok bünügyi személyes adatok, amelyek a 3. pont szerint különleges adatnak minősülnek. Az elhatárolásból fakadóan viszont nem felelnek meg a minősített adattá nyilvánításhoz szükséges feltételeknek, amelyek következtében teljesülhetne a zárt tárgyalás elrendelésével kapcsolatos kitétel.

A jelenlegi eljárás tükrében kiszorul a nyilvánosság az igazságszolgáltatás érdemi részéből, az eljárást lezáró határozat meghozatalából; az ítélet teljes terjedelemben történő megismerhetőségének hiányában nem érvényesül az a társadalmi kontroll, ami az igazságszolgáltatás átláthatóságát hivatott szavatolni. A 237. § (3) bekezdése arra enged következtetni, hogy a zárt tárgyalás elrendelésének célja a jó erkölcsnek, az eljárásban részt vevőknek és a minősített adatok védelmének megőrzése, ezzel szemben a szabályozás azt idézi elö, hogy az eljáráson kívüli, külső szereplők sem ismerhetik meg azo- 
kat a bizonyítékokat, amelyekre a bíróság a határozatát alapozta, annak ellenére sem, hogy ezek az értékek jelen esetben nem állnak veszélyben. Nincs olyan fenyegetettség, amely közvetlenül érinthetné az így felvetődő érdekeket, és indokolttá tehetné a szabályozást. Ez a metódus ebből kifolyólag nem feleltethető meg sem a nyilvánosság elvének, sem pedig a véleménynyilvánítás szabadságához való jognak, ami a kommunikációs jogok anyajogaként magában foglalja a közérdekü adatok megismeréséhez füződő jogot, amelyet az alaptörvény VI. cikk (2) bekezdése tartalmaz, valamint az információs önrendelkezési jogot. Habár a véleménynyilvánításhoz való jog nem abszolút, korlátozhatatlan alapjog, az Alkotmánybíróság gyakorlata értelmében mégis fokozott alkotmányjogi védelmet élvez. Kitüntetett szerepe azzal jár, hogy ,,igen kevés joggal szemben kell csak engednie, azaz a véleményszabadságot korlátozó törvényeket megszoritóan kell értelmezni”. „A vélemény szabadságával szemben mérlegelendö korlátozó törvénynek nagyobb a súlya, ha közvetlenül másik alanyi alapjog érvényesitésére és védelmére szolgál, kisebb, ha ilyen jogokat csakis mögöttesen, valamely intézmény közvetitésével véd, s legkisebb, ha csupán valamely elvont érték önmagában a tárgya (például a köznyugalom)" [30/1992. (V. 26.) AB határozat]. ${ }^{2}$ Mivel jelen esetben nincs olyan törvényi szabályozás, ami indokolttá tenné a titkosságot, továbbá a társadalmi érdek is az igazságszolgáltatás müködésének átláthatósága mellett szól, ezért nem áll rendelkezésre olyan legitim ok, amely ne támaszthatná alá az ítélet megalapozásául szolgáló indokolás megismerhetővé tételét, ezáltal a vád bizonyítékait és azt a logikai folyamatot, amelynek eredményeképpen a bíróság határozata megszületett. Mindezekből kifolyólag jól látható, hogy ez a gyakorlat nem felel meg a szükségesség és arányosság tesztjének, ugyanis a jogkorlátozás mint eszköz nem áll arányban a vele szemben álló céllal.

\section{Az információs önrendelkezési jog korlátozása}

Ezen felül a terhelt ügymegismerési joga is korlátozva van a Be. 205. § (2) bekezdése alapján azáltal, hogy , a titkos adatszerzés tényét, valamint az azzal beszerzett és rögzitett adatot a titkos adatszerzés végrehajtása során, illetőleg azt követöen mindaddig, amig a titkos adatszerzésröl szóló jelentést az ügyész nem csatolta az iratokhoz, az engedélyezö biró, az ügyész és a nyo-

\footnotetext{
2 Sári János - Somody Bernadette: Alapjogok - Alkotmánytan II. Negyedik, átdolgozott kiadás. Osiris Kiadó, Budapest, 2008, 164. o.
} 
mozó hatóság, valamint az ügyész és a nyomozó hatóság hivatali felettese (szolgálati elöljárója) ismerheti meg”. A gyanúsított a gyanú közlésétől kezdve gyakorolhatja az eljárás során őt megillető jogokat, így az iratokba való betekintés jogát is, de csak abban az esetben, ha az a nyomozás érdekeit nem veszélyezteti. E szabályozás célja, hogy a gyanúsított ne szerezhessen tudomást a titkos adatszerzés foganatosításáról, ily módon garantálva a nyomozás sikerességét. Az információs önrendelkezési jogból eredően a gyanúsítottnak jogában áll, hogy megismerhesse a személyes adatait, és rendelkezzen fölöttük, így különösen a bünügyi személyes adatai fölött, azonban a nyomozás lefolytatásának sikerességéhez füződő társadalmi érdek ebben a helyzetben megalapozottá teheti az alapjog korlátozását, és ennek során az iratokba való betekintés lehetőségének szükítését.

„A jelenlegi titkositási gyakorlat arra alapozódik, hogy az információk forrásai titkos együttmüködök, vagy más szerv, partnerszerv, titkosszolgálat által átadott, hasonlóan minösitett adatai alapján indul az információ ellenörzése. Az együttmüködők, fedett nyomozók adatai természetesen továbbra is minösitetten kezelhetök, de az új szellemü nyomozás szerint az általuk konkrét büncselekményekre vonatkozó információknak a nyilt nyomozati tevékenységet, illetve az annak elökészitését szolgáló információ-ellenörzéseket kell támogatniuk." A kapcsolattartó nyomozónak arra kell törekednie, hogy olyan információkat szerezzen be, amelyeket majd minősítés nélkül is bele tud foglalni a jelentésébe. ${ }^{3}$ Ezáltal válik biztosíthatóvá az, hogy az eljárás iratanyaga ne tartalmazzon olyan adatokat, amelyek okán később a terhelt eljárási jogait szúkíthetik, valamint elrendelhetővé válhat a zárt tárgyalás, és így az ítélet indokolásából a nyilvánosság kirekesztése.

\section{Összegzés}

Összességében elmondhatjuk, hogy a titkos információgyüjtés, valamint a titkos adatszerzés szabályozása csak az alkotmányos jogállamok esetében kérdés, mert ahol nem a jog uralma érvényesül, ott az önkény nem támaszt keretet a különleges eszközök alkalmazásának. Mindazonáltal az alaptörvény szövege és értékrendszere alapján hazánkban jelentősége van annak, hogy a megalkotott jogszabályok beteljesítsék a velük szemben támasztott elvárásokat, és a jogbiztonságból fakadóan befedjék azokat a joghézagokat, amelyek

3 Nyeste Péter: A titkos információszerzés szükséges és lehetséges reformja. Belügyi Szemle, 2015/1. 
utat engedhetnek az egyedi jogértelmezésnek. Gustav Radbruch megfogalmazása szerint: ,, valamiféle értékkel minden törvény rendelkezik, tekintet nélkül tartalmára: még mindig jobb bármiféle törvény, mint semmiféle, mert legalább jogbiztonságot teremt" ". A modern jogászi gondolkodásban viszont már nem elégedhetünk meg ennyivel, ugyanis a jogbiztonságnak összhangba kell kerülnie az igazságossággal is, annak érdekében, hogy az állam garanciát adhasson a polgárainak a fedett nyomozás alkalmazásával szemben a nemzetközi dokumentumokban is rögzített jogaik vonatkozásában.

Ezek az eszközök ugyanis a magánszféra olyan mélységeit érintik, amelybe önszántunkból csak nagyon keveseket engedünk be, és az államtól tartózkodást várunk el ezen a területen az egzisztenciánk megőrzése érdekében. Az emberi méltósághoz való jog mint általános személyiségi jog, annyira erős alapjog, amely csakis olyan jogkorlátozásokkal szemben enged, amelyek megfelelnek a szükségesség és arányosság követelményének. Mind a titkos információgyüjtés, mind pedig a titkos adatszerzés olyan nevesített jogokat érint, mint például a magán- és családi élethez való jog, az otthon, a kapcsolattartás, a jó hírnév tiszteletben tartásához füződő jog, továbbá a magántitokhoz, a magánlakás sérthetetlenségéhez való jog, amelyek a privátszféra legalapvetőbb építőkövei. Az ezekhez kötődő társadalmi érdek megköveteli, hogy legyen egy magasabb rendủ cél, amely indokolttá és ennek révén elengedhetetlenné teheti az intézkedéseket. Ehhez azonban arra is szükség van, hogy a beavatkozás indokát egy olyan jól kialakított szabályrendszer vegye körül, ami következetességet és átláthatóságot mutat annak érdekében, hogy az eljárás valóban megfelelhessen a jogállamiság feltételeinek. Ennek érdekében elengedhetetlen a nemzetközi trendek nyomon követése, az Alkotmánybíróság döntéseinek figyelembevétele, valamint az összhangban lévő és egymásra épülő bírói gyakorlat kimunkálása, tekintettel arra, hogy ezek a források nem pusztán az állam érdekeit szolgálják, hanem a társadalom igényeire is érzékenyen képesek reagálni az aktuális politikai környezettől függetlenül is. Ennek a környezetnek a megteremtése során, Radbruchot idézve, ,,az emberi jogokra hivatkozunk, melyek felette állanak minden írott jogtételnekvagyis az elvonhatatlan és kétségbevonhatatlan jogra, mely embertelen zsarnokok bünös parancsaitól elvitatja az érvényességet". ${ }^{5}$

\footnotetext{
4 Gustav Radbruch: Törvényes jogtalanság és törvényfeletti jog. In: Varga Csaba (szerk.): Jog és filozófia. Antológia a XX. század jogi gondolkodása köréből. Ötödik kiadás. Szent István Társulat, Budapest, 2008, 234. o.

5 Uo.
} 
Mindehhez egy olyan apparátusnak is jelen kell lennie, amely diszkréten és célhoz kötötten képes ellátni a feladatát, azonban jelen állapot szerint „,egyetlenek vagyunk a volt szocialista országok között, ahol a rendörségnek nincs olyan saját szervezeti egysége, amely a figyeléseket, telefonlehallgatásokat és egyéb operativ felderitési tevékenységeket elvégezne". ${ }^{6}$ Ennek hiányossága azzal a következménnyel jár, hogy „az igazságszolgáltatás kénytelen a polgári és katonai titkosszolgálatokat is kiszolgáló titkosszolgálati képességeket igénybe venni. Elsö laikus ránézésre ez nem okoz gondot, söt racionális szempontokkal indokolhatónak tünik, de szakmai, jogi szürön keresztül nézve, ha a bünüldözés és az igazságszolgáltatás meghatározott feladatait egyazon titkosszolgálat hajtja végre, akkor egyrészröl annak ellenőrizhetősége, a bíróság általi felhasználhatósága, bünügyi szakmaisága erösen megkérdöjelezhetö, egyszersmind ez a titkosszolgálatok feladatai tekintetében is biztonsági kockázati tényezö lehet. Az elmúlt évek tapasztalatai alapján ténybelileg megállapitható, hogy a nyomozó hatóságok bünügyi felderitö, nyomozati eljárásai során jelentösen megnött a nemzetbiztonsági szakszolgálatra való ráutaltság (például rendörség megfigyelési képességének nemzetbiztonsági szakszolgálathoz telepitése), miközben a titkosszolgálat szolgáltatási kapacitásai nem igazodtak ehhez, azaz jelentös kapacitáshiányt idézett elö." ,Szakmailag és törvényességi szempontok szerint is erösen megkérdöjelezhetö, hogy például egy bünügyi, jogi elöképzettséggel nem biró nemzetbiztonsági alkalmazott hogyan képes - mondjuk egy telefonlehallgatás során - megállapitani a bünügy mélyebb összefüggései nélkül, hogy mely közleményeknek van bünügyi relevanciájuk, melyek válhatnak tárgyi bizonyítási eszközzé."”

A hatásköri eltérésekből adódó ellentmondásokat csak egy teljes körü szabályozással lehet feloldani, amelynek képesnek kell lennie lefedni ezeknek a jogintézményeknek valamennyi elemét. A szükséges szervezetrendszer felállításával és az ezekhez nélkülözhetetlen technikai eszközök biztosításával például jelentősen felgyorsítható a beszerzett adatok feldolgozása. Ha egy olyan személy végzi a titkos információgyüjtést, akinek magának is megfelelő bünüldözői tapasztalata van az igazságszolgáltatás területén, és tisztában van azzal, milyen információk lesznek azok, amelyek relevánsak az adott ügyben, az megoldást jelenthetne a „haladéktalanság” kérdésére, és kihatással lehetne a megfigyelt személyi kör leszükítésére is. Ha az erőforrásainkat

6 Ritter Ildikó: Büntető igazságszolgáltatás a kábítószerpiac ellen. Belügyi Szemle, 2014/9.

7 Nyeste Péter: i. m. 
gazdaságosan az adott célra összpontosítjuk, akkor az kevesebb feldolgozandó adatot indukál, ami gyorsítja és könnyebben elbírálhatóvá teszi a rendelkezésre álló adatokat. A célhoz kötöttség emellett biztosíthatja azt, hogy valóban csak az engedélyben szereplő személyre és cselekményre irányuljon a nyomozás, és kisebb valószínúsége legyen annak, hogy az állam jogosulatlanul visszaél a lehetőségeivel, vagy hogy másokat indokolatlanul tegyen ki az eljárással járó jogkorlátozásoknak.

A legfőbb feladat azonban, ami feltehetően már csak az új büntetőeljárási törvényben lesz szabályozva, az hogy a tárgyalás során felhasznált bizonyítékok valóban megismerhetővé váljanak, mert az igazságszolgáltatás csak akkor tud a követelményeknek megfelelően dolgozni, és csak akkor lehet kellő visszatartó ereje, ha a nyilvánosságnak is teret engedünk. Mivel a titkos információgyüjtés és a titkos adatszerzés szabályozása hazánkban még relatíve újszerü, ezért szükséges egy olyan jogi kultúra kialakítása, amely az eredményesség mellett az alapjogok védelmét is képes garantálni. Ehhez észszerü lehet olyan külföldi államok eljárásjogának tanulmányozása, amelyekben már letisztult és nemzetközileg is elfogadott gyakorlat épült ki. Ennek különös jelentősége van annak kapcsán is, hogy napjainkban az országok határai könnyedén átjárhatók, és a durkheimi elvek szerint a társadalom szükségképpeni velejárója a deviáns viselkedés, a bünözés; tehát megvan az esély arra, hogy olyan államok polgárai is a magyar joghatóság alá tartozzanak, amelyek jogrendszere több jogot garantál számukra a megfigyelés alatt. Ebből kifolyólag ezek a személyek méltánytalanul is hátrányba kerülnek a magyar jog alkalmazásával, mint a saját nemzeti jogukéval.

Ilyen mintaként szolgálhat például Hollandia vagy Belgium, amely elfogadja a különleges eszközök használatát a bünfelderítési célok érdekében, viszont a tárgyaláson már nem lehetnek részei a bizonyításnak, ki vannak rekesztve a bizonyítékok közül.

Ezzel szemben áll az Amerikai Egyesült Államok korábbi jogalkotása, amely 1978-ban elfogadta ,, a külföldi hírszerzési megfigyelési törvényt (FISA), melynek 702. szakasza alapján az USA birói meghatalmazással megfigyeli a száloptikai kábeleken haladó adatforgalmat, hogy ellenörizze a külföldön élö külföldieknek az amerikai távközlési rendszereken áthaladó elektronikus leveleit, webes chatelését, szöveges üzeneteit és más kommunikációját. A törvénybe 2008-ban beillesztett 702. szakasz tartalmazza az úgynevezett PRISM programot, amelynek segitségével az NSA külföldi hirszerzési adatokat gyüjt a Google, Facebook, Microsoft, Apple és szinte mindegyik nagy amerikai táv- 
közlési cégen keresztül folyó kommunikációról." " Enyhülés azonban megfigyelhető ezen a téren, mivel a terrorcselekmények hatására 2001-ben megszavazott Patriot Actet, amely lehetővé tette a titkosszolgálatoknak, hogy emberek millióinak magánbeszélgetéseit hallgassák le, a begyüjtött személyes adatokból adatbázist építsenek, és így kutassanak potenciális gyanúsítottak után, 2015-ben már nem hosszabbította meg a kongresszus ${ }^{9}$, ezzel valamelyest jobban garantálhatóvá vált, hogy az állami paranoia ne legyen elfogadható indoka a magánszférába való behatolásnak.

Be kell látnunk, hogy különösen nagy jelentőségük van ezeknek a garanciáknak egy olyan világban, amelyben az emberek leragasztják a számítógépük webkameráját, mert köztudott, hogy ezeken keresztül bárki a hackerek áldozatává válhat. A modern államok vonatkozásában a különleges eszközök alkalmazása sok esetben elengedhetetlen része lett a nyomozási tevékenységnek, azonban szükség van olyan keretek felállítására, amelyek képesek gátat szabni az önkénynek és a törvények egyéniesített értelmezésének. Csak így lehet elérni az informatikai forradalom által okozott létbizonytalanság és kiszolgáltatottság szinten tartását, ha már a teljes harmónia megteremtésére való törekvés a kezdetektől fogva esélytelennek mutatkozik is.

\footnotetext{
8 Titkos adatgyüjtés. Szakértői bizottság: a megfigyelés a terrorizmus elleni harc egyik leghatékonyabb eszköze. Galamus.hu, 2014. július 3.

http://www.galamus.hu/index.php?option=com_content\&view=article\&id=392509_titkos_adatgyujtes_szakertoi_bizottsag_a_a_elleni

9 Véget ért a tömeges megfigyelések kora Amerikában. Origo.hu, 2015. június 1.

http://www.origo.hu/techbazis/20150601-lehallgatas-amerika-freedom-act-usa-szavazas-torveny-

patriot-torvenycikk-nemzetbiztonsag.html
} 